NATIONAL LABORATORY

\title{
Density of Gadolinium Nitrate Solutions for the High Flux Isotope Reactor
}

\section{May 2009}

\author{
Prepared by
}

P. A. Taylor and D. L. Schuh

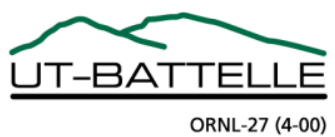




\title{
DOCUMENT AVAILABILITY
}

Reports produced after January 1, 1996, are generally available free via the U.S. Department of Energy (DOE) Information Bridge.

Web site http://www.osti.gov/bridge

Reports produced before January 1, 1996, may be purchased by members of the public from the following source.

\author{
National Technical Information Service \\ 5285 Port Royal Road \\ Springfield, VA 22161 \\ Telephone 703-605-6000 (1-800-553-6847) \\ TDD 703-487-4639 \\ Fax 703-605-6900 \\ E-mailinfo@ntis.gov \\ Web site http://www.ntis.gov/support/ordernowabout.htm
}

Reports are available to DOE employees, DOE contractors, Energy Technology Data Exchange (ETDE) representatives, and International Nuclear Information System (INIS) representatives from the following source.

Office of Scientific and Technical Information

P.O. Box 62

Oak Ridge, TN 37831

Telephone 865-576-8401

Fax 865-576-5728

E-mail reports@osti.gov

Web site http://www.osti.gov/contact.html

This report was prepared as an account of work sponsored by an agency of the United States Government. Neither the United States Government nor any agency thereof, nor any of their employees, makes any warranty, express or implied, or assumes any legal liability or responsibility for the accuracy, completeness, or usefulness of any information, apparatus, product, or process disclosed, or represents that its use would not infringe privately owned rights. Reference herein to any specific commercial product, process, or service by trade name, trademark, manufacturer, or otherwise, does not necessarily constitute or imply its endorsement, recommendation, or favoring by the United States Government or any agency thereof. The views and opinions of authors expressed herein do not necessarily state or reflect those of the United States Government or any agency thereof. 


\title{
DENSITY OF GADOLINIUM NITRATE SOLUTIONS FOR THE HIGH FLUX ISOTOPE REACTOR
}

\author{
P. A. Taylor and D. L. Schuh
}

Date Published: May 2009

\author{
Prepared by \\ OAK RIDGE NATIONAL LABORATORY \\ Oak Ridge, Tennessee 37831-6283 \\ managed by \\ UT-BATTELLE, LLC \\ for the \\ U.S. DEPARTMENT OF ENERGY \\ under contract DE-AC05-00OR22725
}





\section{CONTENTS}

Page

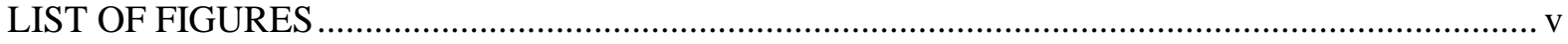

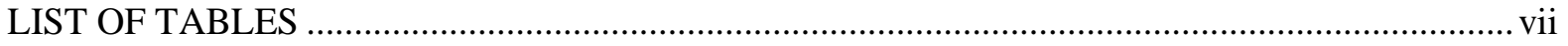

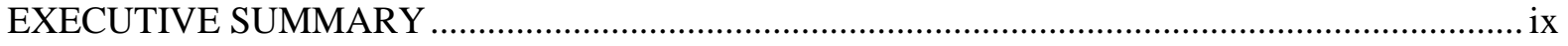

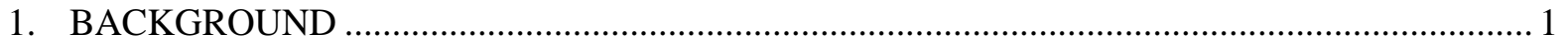

2. DESCRIPTION OF THE HFIR POISON INJECTION SYSTEM …...................................... 2

3. CALCULATION OF DENSITY-CONCENTRATION CORRELATION …............................. 3

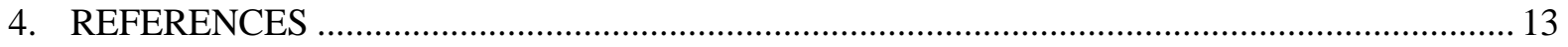





\section{LIST OF FIGURES}

Figure

Page

1 Current worksheet for calculating the quantity of gadolinium in the poison injection system tank

Gadolinium nitrate solution densities, from references 1 and 2, at various

concentrations and temperatures.......

Gadolinium nitrate solution densities, published and calculated

$4 \quad$ Graph of wt $\% \mathrm{Gd}\left(\mathrm{NO}_{3}\right)_{3}$ vs density, from procedure STPF-1410.1 ............................ 9

$5 \quad$ Graph of gadolinium concentration vs density at $5^{\circ} \mathrm{C}$, from references 1 and $2 \ldots \ldots \ldots \ldots . . .10$ 



\section{LIST OF TABLES}

Table

Page

1 Density of gadolinium nitrate-water solutions at $25^{\circ} \mathrm{C}$

4

Coefficients for power function equation to calculate gadolinium chloride solution

densities .....

4

3 Density of gadolinium chloride solutions .............................................................. 5

4 Ratios of gadolinium chloride solution densities at each temperature, compared

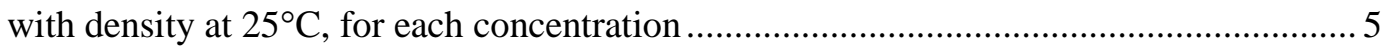

5 Calculated densities of gadolinium nitrate solutions at various temperatures (from

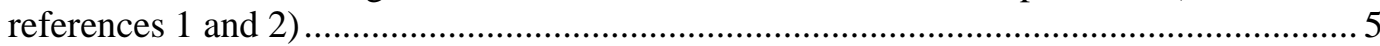

$6 \quad$ Density of gadolinium nitrate solutions at various temperatures................................... 7

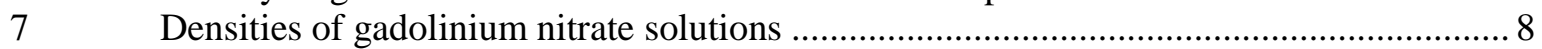





\section{EXECUTIVE SUMMARY}

In late 1992, the High Flux Isotope Reactor (HFIR) was planning to switch the solution contained in the poison injection tank from cadmium nitrate to gadolinium nitrate. The poison injection system is an emergency system used to shut down the reactor by adding a neutron poison to the cooling water. This system must be able to supply a minimum of 69 pounds of gadolinium to the reactor coolant system in order to guarantee that the reactor would become subcritical. A graph of the density of gadolinium nitrate solutions over a concentration range of 5 to $30 \mathrm{wt} \%$ and a temperature range of 15 to $40^{\circ} \mathrm{C}$ was prepared. Routine density measurements of the solution in the poison injection tank are made by HFIR personnel, and an adaptation of the original graph is used to determine the gadolinium nitrate concentration. In late 2008, HFIR personnel decided that the heat tracing that was present on the piping for the poison injection system could be removed without any danger of freezing the solution; however, the gadolinium nitrate solution might get as cold as $5^{\circ} \mathrm{C}$. This was outside the range of the current density-concentration correlation, so the range needed to be expanded. This report supplies a new density-concentration correlation that covers the extended temperature range. The correlation is given in new units, which greatly simplifies the calculation that is required to determine the pounds of gadolinium in the tank solution.

The procedure for calculating the amount of gadolinium in the HFIR poison injection system is as follows.

1. Calculate the usable volume in the system

2. Measure the density of the solution

3. Calculate the gadolinium concentration using the following equation:

$$
\operatorname{Gd}\left(\mathrm{lb} / \mathrm{ft}^{3}\right)=\text { measured density }(\mathrm{g} / \mathrm{mL}) \times 34.681-34.785
$$

4. Calculate the amount of gadolinium in the system using the following equation:

$$
\text { Amount of } \mathrm{Gd}(\mathrm{lb})=\mathrm{Gd} \text { concentration }\left(\mathrm{lb} / \mathrm{ft}^{3}\right) \times \text { usable volume }\left(\mathrm{ft}^{3}\right)
$$

The equation in step 3 is exact for a temperature of $5^{\circ} \mathrm{C}$, and overestimates the gadolinium concentration at all higher temperatures. This guarantees that the calculation is conservative, in that the actual concentration will be at least as high as that calculated. If an additional safety factor is desired, it is recommended that an administrative control limit be set that is higher than the required minimum amount of gadolinium. 



\section{BACKGROUND}

In late 1992 Ken Morgan (Research Reactors Division) asked Paul Taylor (Chemical Technology Division, currently the Nuclear Science and Technology Division) to supply a graph of the density of gadolinium nitrate solutions over a concentration range of 5 to $15 \mathrm{wt} \%$, which was later expanded to a maximum of $30 \mathrm{wt} \%$, and a temperature range of 15 to $40^{\circ} \mathrm{C}$. The High Flux Isotope Reactor (HFIR) was planning to switch the solution contained in the poison injection tank from cadmium nitrate to gadolinium nitrate. The poison injection system is an emergency system that can be used to shut down the reactor by adding a neutron poison to the cooling water. The density values were obtained from two published papers. ${ }^{1,2}$ The first paper had density values for solutions of gadolinium nitrate in water over the desired range of concentrations, but only at $25^{\circ} \mathrm{C}$, while the second paper had data for the density of gadolinium chloride over the desired range of concentrations and temperatures. The ratio of density change from $25^{\circ} \mathrm{C}$ for each of the desired temperatures at each concentration was calculated from the gadolinium chloride solution data, and then these ratios were used to calculate the density of gadolinium nitrate solutions at these conditions by multiplying the density at $25^{\circ} \mathrm{C}$ by the appropriate ratio.

In late 2008, HFIR personnel decided that the heat tracing that was present on the piping for the poison injection system could be removed without any danger of freezing the solution; however, the gadolinium nitrate solution might get as cold as $5^{\circ} \mathrm{C}$. This was outside the range of the current density-concentration correlation, so the range needed to be expanded.

The control limits for the gadolinium nitrate solution are based on the total quantity of gadolinium in the poison injection system tank. Because the density-concentration correlation was given in wt $\%$ gadolinium nitrate, the procedure to calculate the quantity of gadolinium in the tank was much more complicated than necessary. A copy of the current calculation worksheet is shown in Fig. 1. The height of solution in the tank is measured, and then the usable volume of solution is calculated (steps A and B). These steps would remain the same. A sample of the solution is taken, and the density (specific gravity) of the solution is measured with a hydrometer. The density-concentration correlation is used to determine the concentration of gadolinium nitrate, as wt $\% \mathrm{Gd}\left(\mathrm{NO}_{3}\right)_{3}$ in the solution (step D). The density measurement is also used to calculate the weight of solution, using the volume of solution that was previously calculated (step C). The amount of gadolinium nitrate is then calculated from the weight of solution and the wt $\% \mathrm{Gd}\left(\mathrm{NO}_{3}\right)_{3}$ (step E). Finally the weight of gadolinium is calculated from the weight fraction of gadolinium in $\mathrm{Gd}\left(\mathrm{NO}_{3}\right)_{3}$ (step $\mathrm{F}$ ). Many of these steps could be avoided if the density-concentration correlation were given in units of $1 \mathrm{~b} \mathrm{Gd} / \mathrm{ft}^{3}$ vs density, rather than wt\% $\mathrm{Gd}\left(\mathrm{NO}_{3}\right)_{3}$ vs density.

Section 3 of this report describes the methods for calculating the new concentration-density correlation and gives the new procedure for calculating the amount of gadolinium in the tank. 


\begin{tabular}{|c|c|c|}
\hline \multicolumn{3}{|c|}{ Volume in Tank } \\
\hline in $\div 12$ in/ft & $4.91 \mathrm{ft}^{2}$ & $=\quad \mathrm{ft}^{3}$ of solution \\
\hline \multicolumn{3}{|l|}{ Adjusted level from Step 1.5} \\
\hline \multirow[t]{2}{*}{ B. } & Total Volume & \\
\hline & $0.302 \mathrm{ft}^{3}$ & $=-\mathrm{ft}^{3}$ \\
\hline Volume in Tank (result from A) & Unusable Volume in System & Total Volume \\
\hline \multirow[b]{3}{*}{ (result from B) } & Mass in Tank & \\
\hline & $\times \quad \times 62.4 \mathrm{lb} / \mathrm{ft}^{3}$ & Ibs of solution \\
\hline & $\begin{array}{l}\text { Specific Gravity } \\
\text { (from Step 1.8) }\end{array}$ & \\
\hline D. & Gram Conversion as Percentage & \\
\hline \multicolumn{2}{|l|}{ 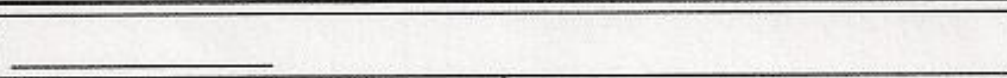 } & $=\quad \%$ \\
\hline $\begin{array}{l}\text { Specific Gravity } \\
\text { from Step } 1.8\end{array}$ & & $\begin{array}{l}\text { From Concentration vs Specific } \\
\text { Gravity Figure }\end{array}$ \\
\hline \multicolumn{3}{|c|}{ nium Nitrate } \\
\hline${ }^{\mathrm{lbs}}$ & $x[$ & $=\_$Ibs of Gadolinium \\
\hline (result from C) & (result from D) & \\
\hline \multicolumn{3}{|c|}{ F. Mass of Gadolinium in the Solution } \\
\hline Ibs & 0.458 & $=$ Ibs of Gadolinium \\
\hline (result from E) & & \\
\hline
\end{tabular}

Fig. 1. Current worksheet for calculating the quantity of gadolinium in the poison injection system tank.

\section{DESCRIPTION OF THE HFIR POISON INJECTION SYSTEM}

Criterion 26 of the Nuclear Regulatory Commission General Design Criteria for Nuclear Power Plants, Appendix A of 10 CFR $50^{3}$, specifies redundancy in a reactivity control system. At HFIR this criterion is met through the use of control plates, the shim regulating cylinder, and the poison injection system. The poison injection system was provided as an alternate mechanism for ensuring nuclear shutdown in the event of very low probability events, which would render the movable shimsafety plates and shim-regulating cylinder ineffective. This system is maintained in the design, in combination with the shim-safety plates and shim-regulating cylinder systems, to provide diverse, redundant nuclear shutdown capability.

Use of the poison-injection system is restricted to conditions when it is impossible to maintain control of the reactor by manipulation of the control elements by any of the normal insertion methods. If all control elements became inoperable during normal power operation, the operating power level would steadily drop to compensate for fuel burnup, and a relatively small negative reactivity would be 
sufficient to maintain the reactor subcritical following xenon decay. If the control elements should become inoperable when reactivity is being steadily increased due to xenon burnout following a scram and restart of the reactor, then (a) sufficient negative reactivity must be available in the poison injection system to shut down with the control elements fully withdrawn, and (b) the response time of the poison injection system must be short enough that the reactor can be shut down before the power is increased to a point that approaches the core thermal limits. This "xenon burnout" scenario was selected to provide the design basis for the system. The maximum negative reactivity required of the system was taken as the excess reactivity of a fresh core with control rods fully withdrawn, and the response time of the system to obtain full injection and mixing of the poison solution was taken as $2 \frac{1}{2} \mathrm{~min}$. The release of soluble poison into the coolant system within $2 \frac{1}{2} 2 \mathrm{~min}$ of a "servo insert error" alarm will shut down the reactor without reaching the core thermal limits, assuming the maximum rate of xenon burnout is consistent with the allowable restart power schedule.

The design of the poison injection system is as follows: The amount of neutron poison available shall be sufficient, when uniformly distributed in the primary coolant system, to completely poison a clean core with the control rods fully withdrawn. The neutron poison shall have a chemical form that is compatible with the materials used in the primary coolant system. The solubility and concentration of the neutron poison shall be such that it has adequate margin for solution under the normal ambient conditions present in the poison injection system. The poison injection system must be operable any time the reactor is operating at power levels greater than $8.5 \mathrm{MW}$.

The material selected to satisfy these criteria for use in the HFIR poison injection system was gadolinium nitrate $\left(\mathrm{Gd}\left(\mathrm{NO}_{3}\right)_{3}\right)$. The amount of gadolinium material required to maintain subcriticality under the above conditions was calculated to be a concentration of 0.6 grams gadolinium per liter of water. This translates to be a minimum of $69 \mathrm{lb}$ of gadolinium (not $\mathrm{Gd}\left(\mathrm{NO}_{3}\right)_{3}$ ) dissolved in the HFIR primary coolant system. The amount of $\mathrm{Gd}\left(\mathrm{NO}_{3}\right)_{3}$ dissolved in the HFIR poison injection system is verified monthly.

\section{CALCULATION OF DENSITY-CONCENTRATION CORRELATION}

Table 1 shows the data on the density of gadolinium nitrate solutions at $25^{\circ} \mathrm{C}$ from reference 1 . The data covers the range of concentrations of interest; however, there is no information on the effect of temperature in this reference. The reference gives the concentrations in molal (moles $/ \mathrm{kg}$ of solvent). The table shows the concentrations in additional units, including weight percent $(\mathrm{wt} \%=$ $\mathrm{g} \mathrm{Gd}\left(\mathrm{NO}_{3}\right)_{3} / 100 \mathrm{~g}$ of solution) and $\mathrm{lb} \mathrm{Gd} / \mathrm{ft}^{3}$ of solution. To convert from molal to wt $\% \mathrm{Gd}\left(\mathrm{NO}_{3}\right)_{3}$, the weight of $\mathrm{Gd}\left(\mathrm{NO}_{3}\right)_{3}$ in the solution is divided by the total weight of solution (water $\left.+\mathrm{Gd}\left(\mathrm{NO}_{3}\right)_{3}\right)$. The equation is as follows:

$$
\mathrm{C}_{2}(\mathrm{wt} \%)=\frac{\mathrm{C}_{1}(\text { moles } / \mathrm{kg} \text { water }) \times \mathrm{MW} \text { of } \mathrm{Gd}\left(\mathrm{NO}_{3}\right)_{3}(\mathrm{~g} / \text { mole })}{\left(1000 \text { g water }+\mathrm{C}_{1}(\text { moles } / \mathrm{kg} \text { water }) \times \mathrm{MW} \text { of Gd }\left(\mathrm{NO}_{3}\right)_{3}(\mathrm{~g} / \text { mole })\right) / 100}
$$

To convert from wt $\% \mathrm{Gd}\left(\mathrm{NO}_{3}\right)_{3}$ to $\mathrm{lb} \mathrm{Gd} / \mathrm{ft}^{3}$ of solution, the weight fraction (wt $\left.\% / 100\right)$ is multiplied by the solution density and by the weight fraction of gadolinium in $\operatorname{Gd}\left(\mathrm{NO}_{3}\right)_{3}$. The equation is as follows:

$$
\mathrm{C}_{3}\left(\mathrm{lb} \mathrm{Gd} / \mathrm{ft}^{3}\right)=\frac{\mathrm{C}_{2}(\mathrm{wt} \%) \times \operatorname{Density}(\mathrm{g} / \mathrm{mL}) \times 62.4\left(\mathrm{lb} / \mathrm{ft}^{3} / \mathrm{g} / \mathrm{mL}\right) \times 0.458\left(\mathrm{lb} \mathrm{Gd} / \mathrm{lb} \mathrm{Gd}\left(\mathrm{NO}_{3}\right)_{3}\right)}{100}
$$


Table 1. Density of gadolinium nitrate-water solutions at $25^{\circ} \mathrm{C}^{1}$

\begin{tabular}{|c|c|c|c|}
\hline \multicolumn{2}{|c|}{$\mathrm{Gd}\left(\mathrm{NO}_{3}\right)_{3}$ concentrations } & \multirow{2}{*}{$\begin{array}{l}\text { Gd conc. } \\
\left(\mathbf{l b ~ G d / f t ^ { 3 }}\right)\end{array}$} & \multirow{2}{*}{$\begin{array}{r}\text { Density } \\
(\mathrm{g} / \mathrm{mL})\end{array}$} \\
\hline (molal) & $(w t \%)$ & & \\
\hline 0.1532 & 4.996 & 1.486 & 1.0409 \\
\hline 0.2068 & 6.628 & 2.000 & 1.0559 \\
\hline 0.2947 & 9.187 & 2.836 & 1.0802 \\
\hline 0.4092 & 12.316 & 3.912 & 1.1113 \\
\hline 0.5991 & 17.057 & 5.662 & 1.1615 \\
\hline 0.7955 & 21.449 & 7.428 & 1.2118 \\
\hline 1.0108 & 25.759 & 9.311 & 1.2648 \\
\hline 1.2150 & 29.431 & 11.048 & 1.3135 \\
\hline
\end{tabular}

Data on the density variation at various temperatures for gadolinium nitrate solutions was not available when the initial density calibration was done; therefore, published data for gadolinium chloride solutions ${ }^{2}$ was used to estimate the density of gadolinium nitrate solutions at various temperatures. Table 2 shows the data from reference 2 , which is in the form of coefficients for a power function equation.

Table 2. Coefficients for power function equation to calculate gadolinium chloride solution densities ${ }^{a}$

\begin{tabular}{ccccccc}
\hline $\begin{array}{c}\text { [Gd Cl} \\
(\mathbf{m o l a l})\end{array}$ & $\mathbf{C}_{\mathbf{0}}$ & $\mathbf{C}_{\mathbf{1}}$ & $\mathbf{C}_{\mathbf{2}}$ & $\mathbf{C}_{\mathbf{3}}$ & $\mathbf{C}_{\mathbf{4}}$ & $\mathbf{C}_{\mathbf{5}}$ \\
\hline 0.0978 & 1.0243 & $2.758 \mathrm{E}-05$ & $-7.673 \mathrm{E}-06$ & $5.884 \mathrm{E}-08$ & $-3.832 \mathrm{E}-10$ & $1.1630 \mathrm{E}-12$ \\
0.2368 & 1.0584 & $-1.761 \mathrm{E}-05$ & $-6.806 \mathrm{E}-06$ & $4.859 \mathrm{E}-08$ & $-3.045 \mathrm{E}-10$ & $8.9523 \mathrm{E}-13$ \\
0.4105 & 1.1002 & $-7.157 \mathrm{E}-05$ & $-5.777 \mathrm{E}-06$ & $3.618 \mathrm{E}-08$ & $-2.075 \mathrm{E}-10$ & $5.6368 \mathrm{E}-13$ \\
0.5894 & 1.1423 & $-1.197 \mathrm{E}-04$ & $-4.996 \mathrm{E}-06$ & $2.863 \mathrm{E}-08$ & $-1.584 \mathrm{E}-10$ & $4.1682 \mathrm{E}-13$ \\
0.7842 & 1.1874 & $-1.696 \mathrm{E}-04$ & $-4.151 \mathrm{E}-06$ & $1.917 \mathrm{E}-08$ & $-8.740 \mathrm{E}-11$ & $1.8198 \mathrm{E}-13$ \\
0.9947 & 1.2349 & $-2.147 \mathrm{E}-04$ & $-3.565 \mathrm{E}-06$ & $1.518 \mathrm{E}-08$ & $-7.142 \mathrm{E}-11$ & $1.5841 \mathrm{E}-13$ \\
1.2239 & 1.2854 & $-2.600 \mathrm{E}-04$ & $-3.038 \mathrm{E}-06$ & $1.258 \mathrm{E}-08$ & $-7.384 \mathrm{E}-11$ & $2.2978 \mathrm{E}-13$ \\
\hline
\end{tabular}

${ }^{a}$ Adapted from Habenschuss and Spedding ${ }^{2}$

Note: Density $=\mathrm{C}_{\mathrm{o}}+\mathrm{C}_{1}(\mathrm{~T})+\mathrm{C}_{2}(\mathrm{~T})^{2}+\mathrm{C}_{3}(\mathrm{~T})^{3}+\mathrm{C}_{4}(\mathrm{~T})^{4}+\mathrm{C}_{5}(\mathrm{~T})^{5}$, where $\mathrm{T}=$ Temperature $\left({ }^{\circ} \mathrm{C}\right)$.

Table 3 shows the densities of gadolinium chloride solutions at various concentrations and temperatures, which were calculated from the equation and coefficients listed above. Table 4 shows the ratio of the density at each temperature to the density at $25^{\circ} \mathrm{C}$ at each concentration. These ratios were used to calculate the density of the gadolinium nitrate solutions at various temperatures, from the published densities at $25^{\circ} \mathrm{C}$. The maximum difference between the densities at $5^{\circ} \mathrm{C}$ and $40^{\circ} \mathrm{C}$ was $1.1 \%$, which occurred at the highest gadolinium chloride concentration, so temperature within this range has a relatively small effect on the density of the solutions. Since the density variation with temperature is small, and gadolinium nitrate and gadolinium chloride solutions should have similar temperature dependencies, using the measured gadolinium chloride temperature dependency to predict the temperature dependency is justified.

Table 5 shows the calculated densities for gadolinium nitrate solutions at various temperatures. The values were calculated from the published densities at $25^{\circ} \mathrm{C}$, shown in Table 1 , and the ratios shown 
Table 3. Density of gadolinium chloride solutions

\begin{tabular}{cccccccccc}
\hline $\begin{array}{c}\text { [Gd Cl } \\
(\mathbf{m o l a l})\end{array}$ & \multicolumn{7}{c}{ Density of solution $(\mathbf{g} / \mathbf{m L})$ at each temperature $\left({ }^{\circ} \mathbf{C}\right)$} \\
\cline { 2 - 8 } & $\mathbf{5}$ & $\mathbf{1 0}$ & $\mathbf{1 5}$ & $\mathbf{2 0}$ & $\mathbf{2 5}$ & $\mathbf{3 0}$ & $\mathbf{3 5}$ \\
\hline 0.0978 & $1.0243 \mathrm{E}+00$ & $1.0239 \mathrm{E}+00$ & $1.0232 \mathrm{E}+00$ & $1.0222 \mathrm{E}+00$ & $1.0210 \mathrm{E}+00$ & $1.0195 \mathrm{E}+00$ & $1.0179 \mathrm{E}+00$ & $1.0160 \mathrm{E}+00$ \\
0.2368 & $1.0581 \mathrm{E}+00$ & $1.0575 \mathrm{E}+00$ & $1.0566 \mathrm{E}+00$ & $1.0553 \mathrm{E}+00$ & $1.0536 \mathrm{E}+00$ & $1.0515 \mathrm{E}+00$ & $1.0490 \mathrm{E}+00$ & $1.0461 \mathrm{E}+00$ \\
0.4105 & $1.0997 \mathrm{E}+00$ & $1.0989 \mathrm{E}+00$ & $1.0978 \mathrm{E}+00$ & $1.0964 \mathrm{E}+00$ & $1.0947 \mathrm{E}+00$ & $1.0927 \mathrm{E}+00$ & $1.0903 \mathrm{E}+00$ & $1.0876 \mathrm{E}+00$ \\
0.5894 & $1.1416 \mathrm{E}+00$ & $1.1406 \mathrm{E}+00$ & $1.1394 \mathrm{E}+00$ & $1.1379 \mathrm{E}+00$ & $1.1361 \mathrm{E}+00$ & $1.1341 \mathrm{E}+00$ & $1.1318 \mathrm{E}+00$ & $1.1292 \mathrm{E}+00$ \\
0.7842 & $1.1864 \mathrm{E}+00$ & $1.1853 \mathrm{E}+00$ & $1.1839 \mathrm{E}+00$ & $1.1823 \mathrm{E}+00$ & $1.1805 \mathrm{E}+00$ & $1.1785 \mathrm{E}+00$ & $1.1763 \mathrm{E}+00$ & $1.1738 \mathrm{E}+00$ \\
0.9947 & $1.2337 \mathrm{E}+00$ & $1.2324 \mathrm{E}+00$ & $1.2309 \mathrm{E}+00$ & $1.2292 \mathrm{E}+00$ & $1.2273 \mathrm{E}+00$ & $1.2252 \mathrm{E}+00$ & $1.2229 \mathrm{E}+00$ & $1.2204 \mathrm{E}+00$ \\
1.2239 & $1.2840 \mathrm{E}+00$ & $1.2825 \mathrm{E}+00$ & $1.2808 \mathrm{E}+00$ & $1.2790 \mathrm{E}+00$ & $1.2770 \mathrm{E}+00$ & $1.2748 \mathrm{E}+00$ & $1.2725 \mathrm{E}+00$ & $1.2700 \mathrm{E}+00$ \\
\hline
\end{tabular}

Table 4. Ratios of gadolinium chloride solution densities at each temperature, compared with density at $25^{\circ} \mathrm{C}$, for each concentration

\begin{tabular}{|c|c|c|c|c|c|c|c|c|}
\hline \multirow{2}{*}{$\begin{array}{c}{\left[\mathbf{G d ~ C l}_{3}\right]} \\
\text { (molal) }\end{array}$} & \multicolumn{8}{|c|}{ Ratio of density at each temperature to the density at $25^{\circ} \mathrm{C}$} \\
\hline & 5 & 10 & 15 & 20 & 25 & 30 & 35 & 40 \\
\hline 0.0978 & 1.0032 & 1.0028 & 1.0021 & 1.0012 & 1.0000 & 0.9986 & 0.9970 & 0.9952 \\
\hline 0.2368 & 1.0043 & 1.0037 & 1.0028 & 1.0016 & 1.0000 & 0.9980 & 0.9957 & 0.9929 \\
\hline 0.4105 & 1.0045 & 1.0038 & 1.0028 & 1.0016 & 1.0000 & 0.9981 & 0.9960 & 0.9935 \\
\hline 0.5894 & 1.0048 & 1.0039 & 1.0029 & 1.0015 & 1.0000 & 0.9982 & 0.9962 & 0.9939 \\
\hline 0.7842 & 1.0050 & 1.0040 & 1.0029 & 1.0015 & 1.0000 & 0.9983 & 0.9964 & 0.9943 \\
\hline 0.9947 & 1.0053 & 1.0042 & 1.0029 & 1.0015 & 1.0000 & 0.9983 & 0.9964 & 0.9944 \\
\hline 1.2239 & 1.0055 & 1.0043 & 1.0030 & 1.0016 & 1.0000 & 0.9983 & 0.9965 & 0.9945 \\
\hline
\end{tabular}

Table 5. Calculated densities of gadolinium nitrate solutions at various temperatures (from references 1 and 2)

\begin{tabular}{|c|c|c|c|c|c|c|c|c|}
\hline \multirow{2}{*}{$\begin{array}{c}{\left[\mathrm{Gd}\left(\mathrm{NO}_{3}\right)_{3}\right]} \\
(\text { molal })\end{array}$} & \multicolumn{8}{|c|}{ Density of solution $(\mathrm{g} / \mathrm{mL})$ at each temperature $\left({ }^{\circ} \mathrm{C}\right)$} \\
\hline & 5 & 10 & 15 & 20 & 25 & 30 & 35 & 40 \\
\hline 0.1532 & 1.0448 & 1.0443 & 1.0435 & 1.0424 & 1.0409 & 1.0391 & 1.0371 & 1.0347 \\
\hline 0.2068 & 1.0605 & 1.0599 & 1.0589 & 1.0576 & 1.0559 & 1.0538 & 1.0513 & 1.0484 \\
\hline 0.2947 & 1.0850 & 1.0843 & 1.0833 & 1.0819 & 1.0802 & 1.0781 & 1.0757 & 1.0729 \\
\hline 0.4092 & 1.1163 & 1.1155 & 1.1144 & 1.1130 & 1.1113 & 1.1092 & 1.1068 & 1.1041 \\
\hline 0.5991 & 1.1671 & 1.1661 & 1.1648 & 1.1633 & 1.1615 & 1.1594 & 1.1571 & 1.1544 \\
\hline 0.7955 & 1.2179 & 1.2167 & 1.2153 & 1.2136 & 1.2118 & 1.2097 & 1.2074 & 1.2049 \\
\hline 1.0108 & 1.2714 & 1.2701 & 1.2685 & 1.2667 & 1.2648 & 1.2626 & 1.2603 & 1.2577 \\
\hline 1.2150 & 1.3207 & 1.3191 & 1.3174 & 1.3155 & 1.3135 & 1.3112 & 1.3088 & 1.3062 \\
\hline
\end{tabular}


in Table 4. Where the gadolinium chloride concentrations were close to the gadolinium nitrate concentrations, the ratios in Table 4 were used directly; otherwise, interpolated values were used to calculate the densities of the gadolinium nitrate solutions.

Figure 2 shows a graph of the densities of gadolinium nitrate solutions at a range of concentrations and temperatures. The concentrations are plotted as $\mathrm{lb} \mathrm{Gd} / \mathrm{ft}^{3}$ of solution. The variation in density caused by the different temperatures is relatively small, with a maximum variation of $1.1 \%$ between $5^{\circ} \mathrm{C}$ and $40^{\circ} \mathrm{C}$. A new paper was published in $2005^{4}$ that gave the density of gadolinium nitrate solutions over a limited range of concentrations and temperatures. The solutions used in these experiments contained a low concentration of nitric acid in addition to the gadolinium nitrate. The data from reference 4 is shown in Fig. 3 and Table 6. In Fig. 3, the densities for the lowest two concentrations of the data from Table 5, which overlap the new data in Table 6, are also plotted for comparison. The two sets of data match very well at the lower temperatures, but there is a slight difference at $40^{\circ} \mathrm{C}$ at the higher concentration. This new data did not extend to the higher concentrations that are used in the poison injection tank at HFIR, or down to the lower temperatures that are desired. Therefore, it is used as a comparison with the densities calculated using the gadolinium chloride temperature variation data, to validate the information in Table 5.

Table 7 shows a comparison of the predicted densities of gadolinium nitrate solutions at the same concentrations using the data from references 1 and 2, where the temperature variation is based on the gadolinium chloride solution data, and the data from reference 4 . The new paper ${ }^{4}$ did not use exactly the same gadolinium nitrate concentrations at each temperature, so interpolation was used to get consistent data, at the same concentrations that were used for the original data from references 1 and 2 , for comparison. The results show that there is a small difference in the predicted densities between the two data sets, particularly at the higher temperatures. The predictions using the data from references 1 and 2, which cover that range of concentrations and temperatures needed by HFIR, give

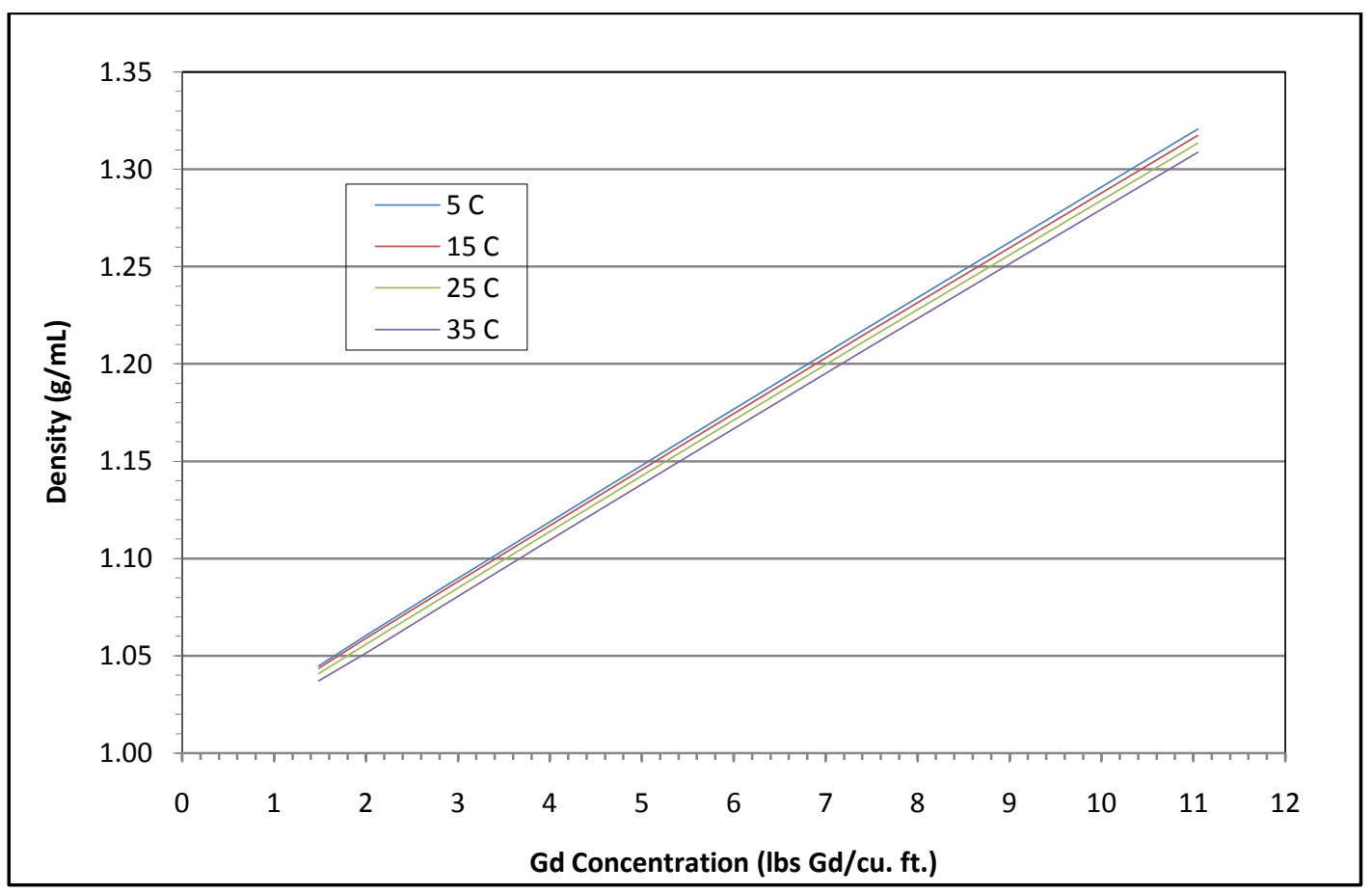

Fig. 2. Gadolinium nitrate solution densities, from references 1 and 2 , at various concentrations and temperatures. 
Table 6. Density of gadolinium nitrate solutions at various temperatures ${ }^{7}$

\begin{tabular}{|c|c|c|c|}
\hline \multicolumn{2}{|c|}{ Concentration (molal) } & \multirow{2}{*}{$\begin{array}{c}\text { Temperature } \\
\left({ }^{\circ} \mathrm{C}\right)\end{array}$} & \multirow{2}{*}{$\begin{array}{r}\text { Density } \\
(\mathrm{g} / \mathrm{mL})\end{array}$} \\
\hline $\mathrm{Gd}\left(\mathrm{NO}_{3}\right)_{3}$ & $\mathrm{HNO}_{3}$ & & \\
\hline 0.01918 & 0.00037 & 15 & 1.004828 \\
\hline 0.03873 & 0.00075 & 15 & 1.010576 \\
\hline 0.05782 & 0.00111 & 15 & 1.016163 \\
\hline 0.07778 & 0.00150 & 15 & 1.021992 \\
\hline 0.09778 & 0.00188 & 15 & 1.027791 \\
\hline 0.11819 & 0.00228 & 15 & 1.033684 \\
\hline 0.13862 & 0.00267 & 15 & 1.039590 \\
\hline 0.15900 & 0.00306 & 15 & 1.045392 \\
\hline 0.18085 & 0.00348 & 15 & 1.051642 \\
\hline 0.20228 & 0.00390 & 15 & 1.057810 \\
\hline 0.01904 & 0.00037 & 25 & 1.002723 \\
\hline 0.03814 & 0.00073 & 25 & 1.008284 \\
\hline 0.05790 & 0.00111 & 25 & 1.014003 \\
\hline 0.07749 & 0.00149 & 25 & 1.019642 \\
\hline 0.09775 & 0.00188 & 25 & 1.025448 \\
\hline 0.11793 & 0.00227 & 25 & 1.031202 \\
\hline 0.13846 & 0.00267 & 25 & 1.037041 \\
\hline 0.15997 & 0.00308 & 25 & 1.043140 \\
\hline 0.18082 & 0.00348 & 25 & 1.049031 \\
\hline 0.20228 & 0.00390 & 25 & 1.055063 \\
\hline 0.01931 & 0.00037 & 40 & 0.997779 \\
\hline 0.05811 & 0.00112 & 40 & 1.008876 \\
\hline 0.07803 & 0.00150 & 40 & 1.014527 \\
\hline 0.09801 & 0.00189 & 40 & 1.020169 \\
\hline 0.11642 & 0.00224 & 40 & 1.025348 \\
\hline 0.13779 & 0.00265 & 40 & 1.031339 \\
\hline 0.15840 & 0.00305 & 40 & 1.037089 \\
\hline 0.18068 & 0.00348 & 40 & 1.043292 \\
\hline 0.20228 & 0.00390 & 40 & 1.049282 \\
\hline 0.01931 & 0.00037 & 40 & 0.997779 \\
\hline
\end{tabular}




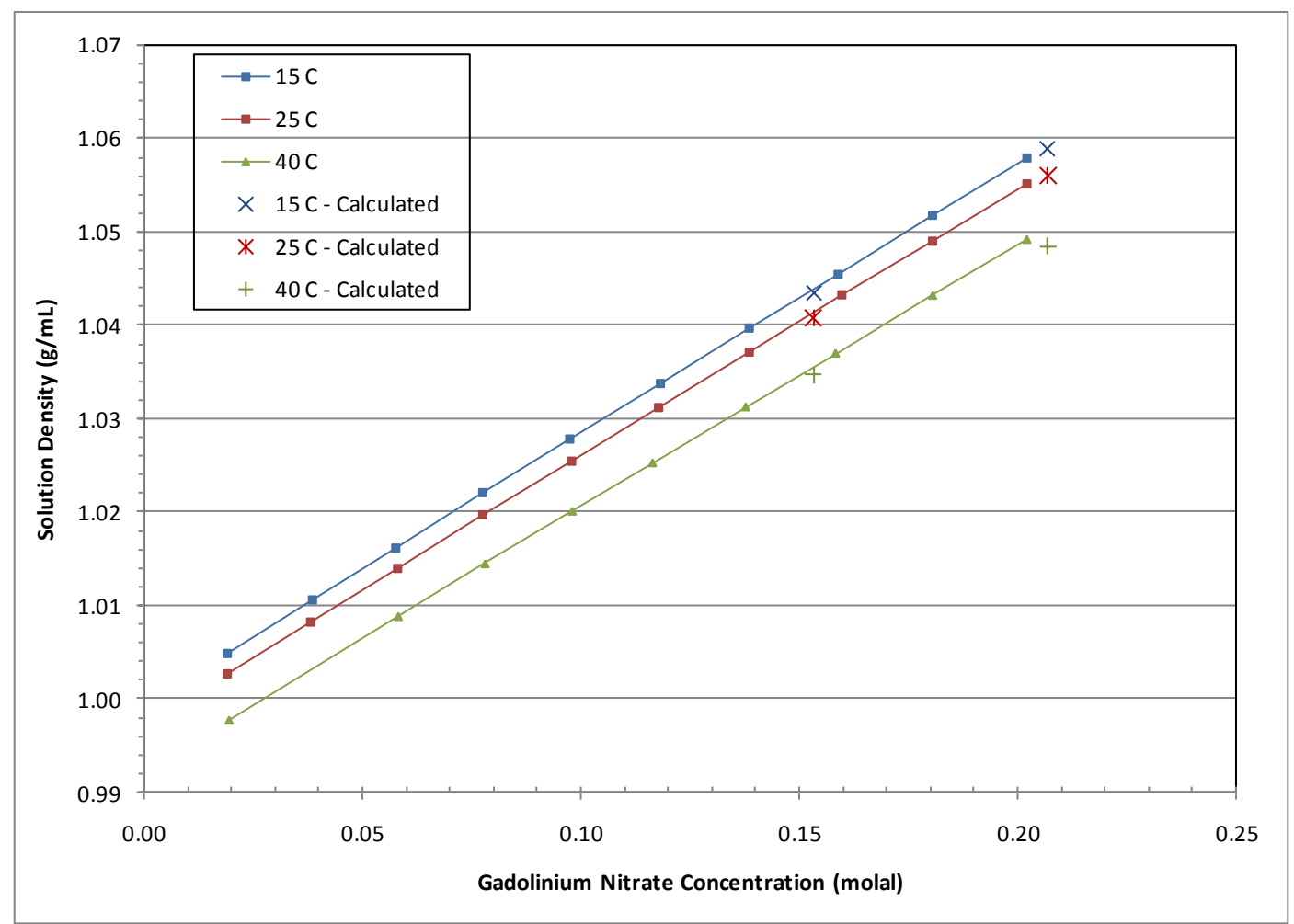

Fig. 3. Gadolinium nitrate solution densities, published ${ }^{4}$ and calculated. ${ }^{1,2}$

Table 7. Densities of gadolinium nitrate solutions

\begin{tabular}{|c|c|c|c|c|}
\hline \multirow{2}{*}{$\begin{array}{c}\mathrm{Gd}\left(\mathrm{NO}_{3}\right)_{3} \\
(\text { molal })\end{array}$} & \multirow{2}{*}{$\begin{array}{c}\text { Temp. } \\
\left({ }^{\circ} \mathrm{C}\right)\end{array}$} & \multicolumn{2}{|c|}{ Density $(g / m L)$} & \multirow{2}{*}{$\begin{array}{c}\text { Variation } \\
(\%)\end{array}$} \\
\hline & & Refs. 1 and 2 & Ref. 7 & \\
\hline 0.1532 & 15 & 1.0435 & 1.0437 & 0.02 \\
\hline 0.1532 & 25 & 1.0409 & 1.0412 & 0.03 \\
\hline 0.1532 & 40 & 1.0347 & 1.0356 & 0.09 \\
\hline 0.2068 & 15 & 1.0589 & 1.0592 & 0.03 \\
\hline 0.2068 & 25 & 1.0559 & 1.0565 & 0.06 \\
\hline 0.2068 & 40 & 1.0484 & 1.0507 & 0.22 \\
\hline
\end{tabular}

a slightly lower density at each concentration. The difference may be the result of the extra concentration of nitric acid in the solutions used for the reference 4 data, or just experimental measurement variations between the two sets of data. Since the density differences at $25^{\circ} \mathrm{C}$, where the gadolinium nitrate solution densities were measured in reference 1 , follow the same pattern as the data at the other temperatures, which were predicted from the gadolinium chloride data in reference 2 , there is no evidence that using the temperature variations from the gadolinium chloride solutions is the cause of the differences. 
The reference 4 data gives slightly higher gadolinium nitrate concentrations than the reference 1 and 2 data at each temperature and concentration. For a given measured density, the correlation from the reference 1 and 2 data (Table 5 and Fig. 2) would predict a lower gadolinium nitrate concentration than the reference 4 data. Therefore, using the correlation from the reference 1 and 2 data would give the lowest predicted gadolinium concentration for a given density measurement for the solution in the HFIR poison injection system, which would be conservative for the HFIR application and guarantee that the actual amount of gadolinium in the system is not less than that calculated.

The existing procedure for determining the amount of gadolinium in the HFIR poison injection system uses a graph of density vs concentration at one temperature, which is based on the original data at $15^{\circ} \mathrm{C}$ (Fig. 4). Using the data at the lower temperature predicts the lowest gadolinium concentration for a given measured density, which is conservative. The data in Fig. 4 has a built-in safety factor of about $10 \%$ compared with the actual data calculated from references 1 and 2 . This safety factor helps guarantee that the actual amount of gadolinium in the poison injection system is higher than the calculated amount; however, it also means that the graph loses the direct tie to the published data. For the new extended temperature range, using the density vs concentration data for the lowest expected temperature will give the lowest amount of gadolinium for any measured density. Therefore, the density data at $5^{\circ} \mathrm{C}$ should be used for calculating the amount of gadolinium in the poison injection system, which will guarantee that the actual concentration is at least as high as the predicted concentration. Figure 5 shows a graph of solution density vs gadolinium concentration (as $\mathrm{lb} \mathrm{Gd} / \mathrm{ft}^{3}$ of solution) and also shows the linear regression correlation and $\mathrm{R}$-squared value for this data.

\begin{tabular}{|l|l|l|}
\hline DATA SHEET FOR THE POISON INJECTION SYSTEM GADOLINIUM TEST & REV.9 & $\begin{array}{c}\text { STPF-1410. 1 } \\
\text { Pgge } 1 \text { of } 3\end{array}$ \\
\hline
\end{tabular}

Concentration vs Specific Gravity of Gadolinium Nitrate in Water at 59f

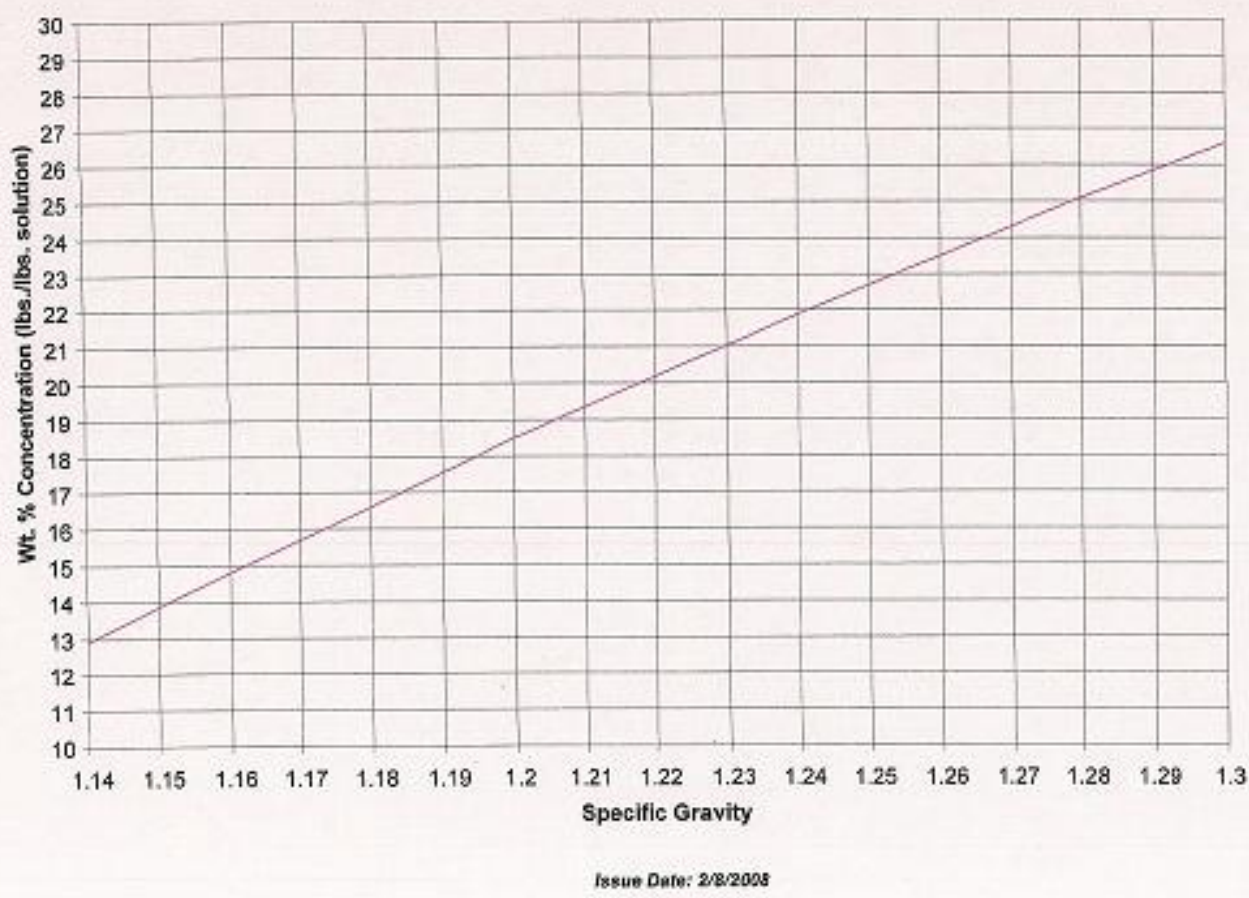

Fig. 4. Graph of wt\% gadolinium nitrate vs density, from HFIR procedure. 


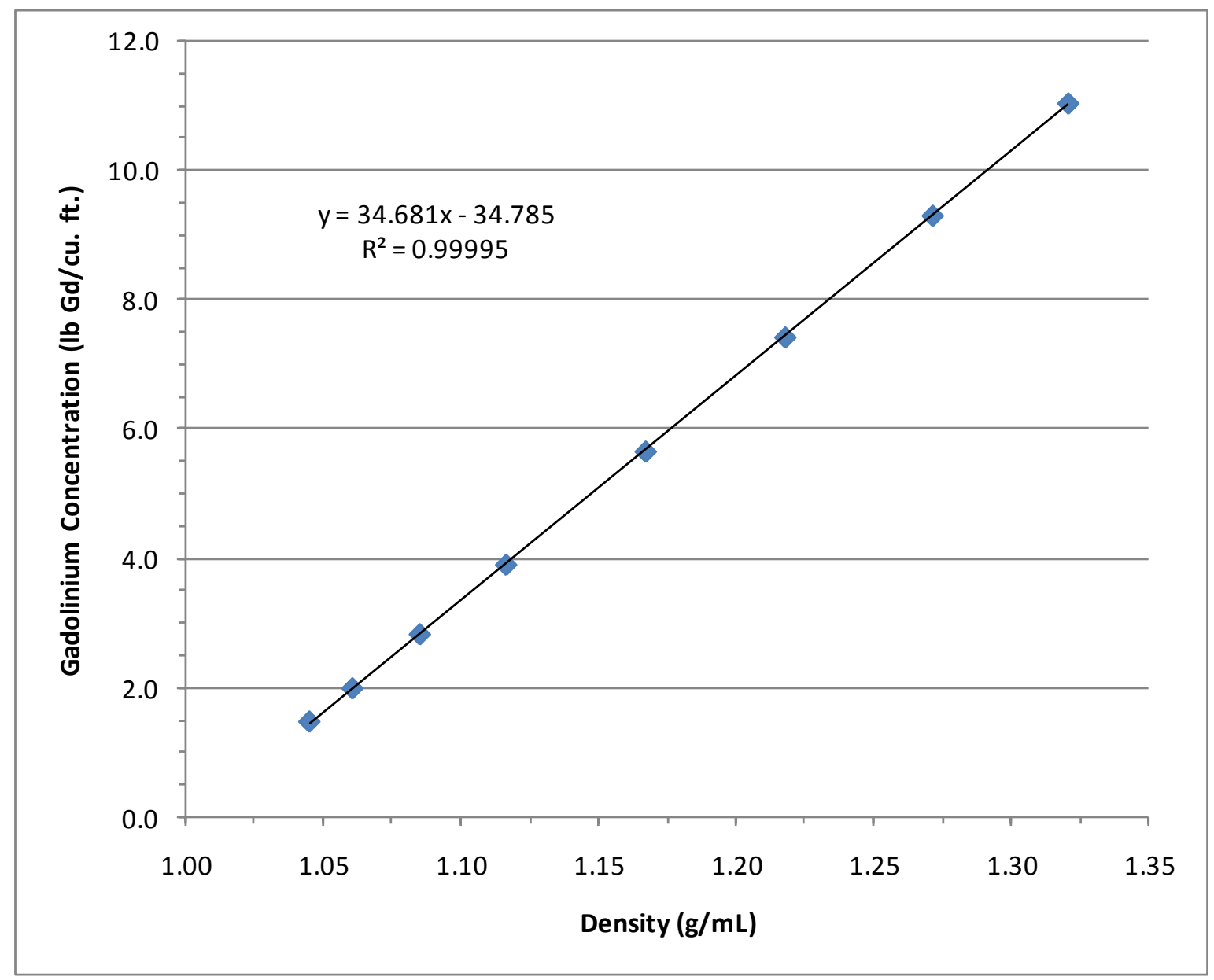

Fig 5. Graph of gadolinium concentration vs density at $5^{\circ} \mathrm{C}$, from references 1 and 2.

The suggested new procedure for calculating the amount of gadolinium in the HFIR poison injection system is as follows.

1 Calculate the usable volume in the system

2. Measure the density of the solution

3. Calculate the gadolinium concentration using the following equation:

$$
\operatorname{Gd}\left(\mathrm{lb} / \mathrm{ft}^{3}\right)=\text { measured density }(\mathrm{g} / \mathrm{mL}) \times 34.681-34.785
$$

or by reading the value from the Fig. 5

4. Calculate the amount of gadolinium in the system using the following equation:

$$
\text { Amount of } \mathrm{Gd}(\mathrm{lb})=\mathrm{Gd} \text { concentration }\left(\mathrm{lb} / \mathrm{ft}^{3}\right) \times \text { usable volume }\left(\mathrm{ft}^{3}\right)
$$

If an additional safety factor is desired, it is recommended that an administrative control limit, which is higher than the required minimum amount of gadolinium, be set, rather than changing the graph in Fig. 5 or the corresponding equation. 
For a typical density of $1.2 \mathrm{~g} / \mathrm{mL}$ in the poison injection system, the equation above would give a gadolinium concentration of $6.83 \mathrm{lb} / \mathrm{ft}^{3}$. The graph in the HFIR procedure would give a concentration of $18.5 \mathrm{wt} \%=6.24 \mathrm{lb} \mathrm{Gd} / \mathrm{ft}^{3}$. Because of the safety factor built into the old graph, this result is about $8 \%$ lower than the actual concentration. 



\section{REFERENCES}

1. F. H. Spedding et al., "Densities and Apparent Molal Volumes of Some Aqueous Rare Earth Solutions at $25^{\circ} \mathrm{C}$," J. of Physical Chemistry 79(11), 1087-1096 (1975).

2. A. Habenschuss and F. Spedding, "Densities and Thermal Expansion of Some Aqueous Rare Earth Chloride Solutions Between $5^{\circ}$ and $80^{\circ} \mathrm{C}$. II. $\mathrm{SmCl}_{3}, \mathrm{GdCl}_{3}, \mathrm{DyCl}_{3}, \mathrm{ErCl}_{3}$, and $\mathrm{YbCl}_{3}$," J. of Chemical \& Engineering Data 21(1), 95-113 (1976).

3. General Design Criteria for Nuclear Power Plants, Appendix A, 10 CFR 50, U.S. Nuclear Regulatory Commission.

4. A. W. Hakin, J. L. Liu, K. Erickson, J.-V.Munoz, and J. A. Rard, “Apparent molar volumes and apparent molar heat capacities of $\operatorname{Pr}\left(\mathrm{NO}_{3}\right)_{3}(\mathrm{aq}), \mathrm{Gd}\left(\mathrm{NO}_{3}\right)_{3}(\mathrm{aq}), \mathrm{Ho}\left(\mathrm{NO}_{3}\right)_{3}(\mathrm{aq})$, and $\mathrm{Y}\left(\mathrm{NO}_{3}\right)_{3}(\mathrm{aq})$ at $\mathrm{T}=(288.15,298.15,313.15$, and 328.15) $\mathrm{K}$ and $\mathrm{p}=0.1 \mathrm{Mpa}, " J$. Chem. Thermodynamics 37, 153-167 (2005). 

ORNL/TM-2009/091

\section{INTERNAL DISTRIBUTION}

1. D. L. Pinkston

2. A. H. Primm

3. D. L. Schuh
4. P. A. Taylor

5. ORNL Office of Technical Information and Classification 